\title{
Serum Amylase and Isoamylase Assay on the Hitachi 705 Automatic Clinical Chemical Analyzer
}

\author{
By Markku T. Parviainen, Timo Koivula and Hannu Jokela \\ Department of Clinical Chemistry, Tampere University Central Hospital, Tampere, Finland
}

(Received May 26/October 31, 1983)

Summary: The automated continuous $\alpha$-amylase assay using $p$-nitrophenyl- $\alpha$ - $D$-maltoheptaoside (Boehringer Mannheim) as substrate on the Hitachi 705 clinical chemical analyzer, was compared with the Phadebas ${ }^{\circledR}$ Kinetic Amylase Assay (Pharmacia Diagnostics) on the Hitachi 705. The two methods showed good correlation.

The precision varied from 1.0 to $2.5 \%$ (CV) within-day and from 1.1 to $5.6 \%$ (CV) day-to-day. The substrate, $p$-nitrophenyl- $\alpha-D$-maltoheptaoside, was also applied to an automated isoamylase assay. The amylase inhibitor from wheat was used to determine the ratio of pancreatic and salivary amylase activities of serum. About $80 \%$ of salivary type amylase was inhibited up to an activity level of $1000 \mathrm{U} / \mathrm{l}$, while inhibition of pancreatic type amylase activity was only $10-15 \%$. Ratios of pancreatic to salivary amylase from 0.1 to 10 can be evaluated in serum with wheat inhibitor. The precision of the isoamylase determination by the Boehringer amylase method was acceptable.

\section{Bestimmung von Amylase und Isoamylase im Serum mit dem Hitachi 705}

Zusammenfassung: Die automatisierte kontinuierliche Bestimmung von $\alpha$-Amylase mit $p$-Nitrophenyl- $\alpha-D$ maltoheptaosid (Boehringer Mannheim) als Substrat mit dem Hitachi 705 wurde mit dem Phadebas ${ }^{\circledR}$ Kinetic Amylase Assay (Pharmacia Diagnostics) am Hitachi 705 verglichen. Beide Methoden zeigen gute Korrelation.

Die Präzision lag in der Serie zwischen 1,0 und 2,5\%, von Tag zu Tag zwischen 1,1 und 5,6\%. Das Substrat $p$ Nitrophenyl- $\alpha-D$-maltoheptaosid wurde auch zur automatisierten Bestimmung von Isoamylase eingesetzt. Der Amylasehemmstoff aus Weizen wurde zur Bestimmung des Verhältnisses von Pankreas-/Speichel-Amylase im Serum verwendet. Speichelamylase bis zu einer katalytischen Konzentration von $1 \mathrm{kU} / \mathrm{l}$ wurde zu etwa $80 \%$ gehemmt, Pankreas-Amylase nur zu 10 bis $15 \%$. Quotienten von Pankreas- und Speichel-Amylase im Serum von 0,1-10 können mit dem Inhibitor aus Weizen untersucht werden. Die Präzision der Bestimmung von Isoamylasé mit der Methode von Boehringer Mannheim war annehmbar.

\section{Introduction}

Continuous amylase assays have recently been introduced by several manufacturers. Unfortunately the various methods are difficult to compare with each other because of differences in the substrates used. At least four different substrates are in common use: $p$-nitrophenyl- $\alpha$ - $D$-maltoheptaoside (Boehringer Mannheim), maltotetraose (General Diagnostics), a mixture of oligosaccharides containing a known amount of polymers with 4 to 10 glucose residues (Merz-Dade) and a carboxymethylated starch (Pharmacia Diagnostics). Differences in the specificity of amylase to these substrates make various standardization procedures necessary. So far no recommended standardization procedure is available for amylase. 
The assay for amylase isoenzymes has been used to separate the various amylase isoenzymes, which mainly originate in the pancreas and salivary glands. Electrophoretic (1-3), electrofocusing and chromatographic (4) techniques, and inhibition tests $(3,5$, 6 ) have been used in this assay. The inhibitor protein from wheat (Triticum aestivum) exhibits 100 -fold specifity for human salivary (S) as compared to human pancreatic (P) amylase (5), which makes it suitable for inhibitor assay of amylase isoenzymes. A RIA method has also been introduced for salivary isoamylase (7).

The aim of this study was to evaluate the application of two continuous amylase tests and of an automated isoamylase assay on the Hitachi 705 automatic clinical chemical analyzer.

\section{Materials and Methods}

$\alpha$-Amylase assay kits

Continuous assay of amylase was performed with the CBR Program $\alpha$-amylase Farbtest kit from Boehringer Mannheim GmbH, Mannheim, F.R.G. and the Phadebas ${ }^{\circledR}$ Kinetic Amylase Kit from Pharmacia Diagnostics, Uppsala, Sweden, who also supplied the Phadebas ${ }^{\circledR}$ Kinetic IsoAmylase Kit.

Automated amylase assay using the Hitachi 705 clinical chemical analyzer

Continuous amylase and isoamylase assays with various kits were performed using a Hitachi 705 (Clinicon, Mannheim, F.R.G.) as shown in table 1 . The table shows essentially the reagent preparation and the chemistry parameters needed for the automated assay.

\section{$\alpha$-Amylase standards}

Human-based Phadebas ${ }^{\circledR}$ IsoAmylase Test Serum Standards (P/S $0.1-8$ ) and Humylase $H, M$ and $L$ control serums containing high, medium and low levels of amylase, and high and low P/S ratios were all from Pharmacia Diagnostics. Isoamylase standards were also prepared in our laboratory from a pooled sample of saliva (total amylase activity concentration $300 \mathrm{kU} /$ ) and from a sample with high pancreatic amylase (total amylase $30 \mathrm{kU} / \mathrm{l}$ ) obtained from a pancreas drain. These samples were diluted in phosphate buffer, $50 \mathrm{mmol} / \mathrm{l}, \mathrm{pH} 6.9$ and assayed for exact amylase activity, and were mixed to yield $\mathrm{P} / \mathrm{S}$ ratios $0.1-10$.

\section{Amylase inhibitors}

Amylase inhibitor from wheat seeds (Triticum aestivum) was obtained from Sigma Chemical Co., St. Louis, MO 63178, containing 2700 inhibiting units per $\mathrm{mg}$ of protein. Inhibitor stock solution was prepared by dissolving the contents of one inhibitor vial ( $5 \mathrm{mg}$ protein corresponding to 13500 inhibiting units) in $1.0 \mathrm{ml}$ of tris buffer, $20 \mathrm{mmol} / \mathrm{l}$ containing $\mathrm{NaCl} 10 \mathrm{mmol} / \mathrm{h}, \mathrm{pH} 8.0$.

This solution was diluted $1 / 100$ in the phosphate buffer, and immediately before use it was further diluted $1 / 4$ in the same buffer.
Tab. 1. An outline of the $\alpha$-amylase assays on the Hitachi 705 Automatic Analyzer.

\section{A. Reagent preparation}

\begin{tabular}{llll}
\hline & $\begin{array}{l}\text { 1. } \\
\text { Boehringer } \\
\text { continuous } \\
\text { amylase }\end{array}$ & $\begin{array}{l}\text { 2. } \\
\text { Phadebas } \\
\text { Kinetic } \\
\text { Amylase }\end{array}$ & $\begin{array}{l}\text { 3. } \\
\text { Phadebas } \\
\text { Kinetic } \\
\text { IsoAmylase }\end{array}$ \\
\hline Reagent 1. & $\begin{array}{l}\text { Dissolve the } \\
\text { reagent vial 2 } \\
\text { in 45 ml of } \\
\text { solution I. } \\
\text { Reagent 2. }\end{array}$ & $\begin{array}{l}\text { Redistilled } \\
\text { wissolve one } \\
\text { substrate vial } \\
\text { in 5 ml of } \\
\text { solution 1. }\end{array}$ & $\begin{array}{l}\text { Dissolve one } \\
\text { inhibitor vial } \\
\text { in 15 ml of } \\
\text { water } \\
\text { one reagent } \\
\text { vial in 20.5 } \mathrm{ml} \\
\text { of water }\end{array}$ \\
\hline
\end{tabular}

B. Chemistry parameters

\begin{tabular}{llll}
\hline Temperature & $37^{\circ} \mathrm{C}$ & $37^{\circ} \mathrm{C}$ & $37^{\circ} \mathrm{C}$ \\
Assay code & $\begin{array}{l}2 \text { (Kinetic)- } \\
25-31\end{array}$ & As in 1. & As in 1. \\
& & & \\
\hline Sample $(\mu \mathrm{l})$ & 10 & 5 & 5 \\
Reagent $1(\mu \mathrm{l})$ & 400 & 250 & 250 \\
Reagent 2 $(\mu \mathrm{l})$ & 40 & 500 & 500 \\
Wavelength 1 (nm) & 660 & 376 & 376 \\
Wavelength 2(nm) & 415 & 340 & 340 \\
\hline
\end{tabular}

The inhibitor solutions were stored frozen. Additionally, inhibitor from the Phadebas ${ }^{\circledR}$ IsoAmylase Test Kit was used and the lyophilized wheat inhibitor redissolved according to the manufacturer's recommendations. The inhibitor solution was diluted $1 / 3$ in the phosphate buffer before use.

\section{Isoamylase assay with inhibition}

$150 \mu$ l of standards, controls or samples were pipetted in duplicate into glass tubes. $150 \mu \mathrm{l}$ of the phosphate buffer was pipetted into one tube of the duplicates and $150 \mu \mathrm{l}$ of the inhibitor working solution into the other. The tubes were mixed and analysed for total amylase activity after at least $5 \mathrm{~min}$ at room temperature. The fraction remaining uninhibited was calculated. Then the standard curve was constructed in which the uninhibited fraction is related to the $\mathrm{P} / \mathrm{S}$ ratio in the standard. The $\mathrm{P} / \mathrm{S}$ ratio in samples and controls was read from this curve. After correcting for the dilution $(\times 2)$ in controls and samples, the $P$ and $S$ isoenzyme activity concentrations were calculated (5):

$\mathrm{P}($ Pancreatic $)$ amylase $(\mathrm{U} / \mathrm{l})=$ Total amylase $\times\left(\frac{\mathrm{P} / \mathrm{S}}{1+\mathrm{P} / \mathrm{S}}\right)$

$S($ Salivary) amylase $(U / I)=$ Total amylase $-P$

In addition the isoamylase assay with the Phadebas ${ }^{\circledR}$ Kinetic IsoAmylase method was also performed on the Hitachi 705. The inhibited and uninhibited reactions were performed automatically in the analyser, which calculated the activities directly. The standard curve relating uninhibited fraction to the $P / S$ ratio was constructed and the results calculated as above. 


\section{Results}

Total continuous amylase assay on the $\mathrm{Hi}$ tachi 705

The routine amylase assay in our laboratory is the Boehringer continuous method for the Hitachi 705 . This was compared with the Phadebas ${ }^{\circledR}$ Kinetic Amylase Test in the same analyser.

The day-to-day and within-day coefficients of variation of the two methods are presented in table 2 . The Boehringer amylase assay is linear at least to 3500 $\mathrm{U} / \mathrm{l}$, whereas the Phadebas ${ }^{\circledR}$ kinetic method in the Hitachi 705 was not linear above $750 \mathrm{U} / \mathrm{l}$.

An excellent correlation was found between the methods compared, as will be seen in figure 1 . The same assay level in the two methods was achieved by standardizing both with human serum. However, the results from various commercially available serums differed considerably from one method to the other. Normally there was no need for daily standardization of the Boehringer amylase method.

\section{Isoamylase assay}

The routine Boehringer continuous total amylase assay was used combined with preliminary incubation of $5 \mathrm{~min}$ with the inhibitor at room temperature to separate the pancreatic $(\mathrm{P})$ isoenzyme from salivary (S) isoenzyme. The incubation time proved to be long enough together with about 10 min processing time of the instrument before starting the measurement. Figure 2 shows the standard curves for the various methods relating the uninhibited amylase fraction to the respective $\mathrm{P} / \mathrm{S}$ ratio in the standard.

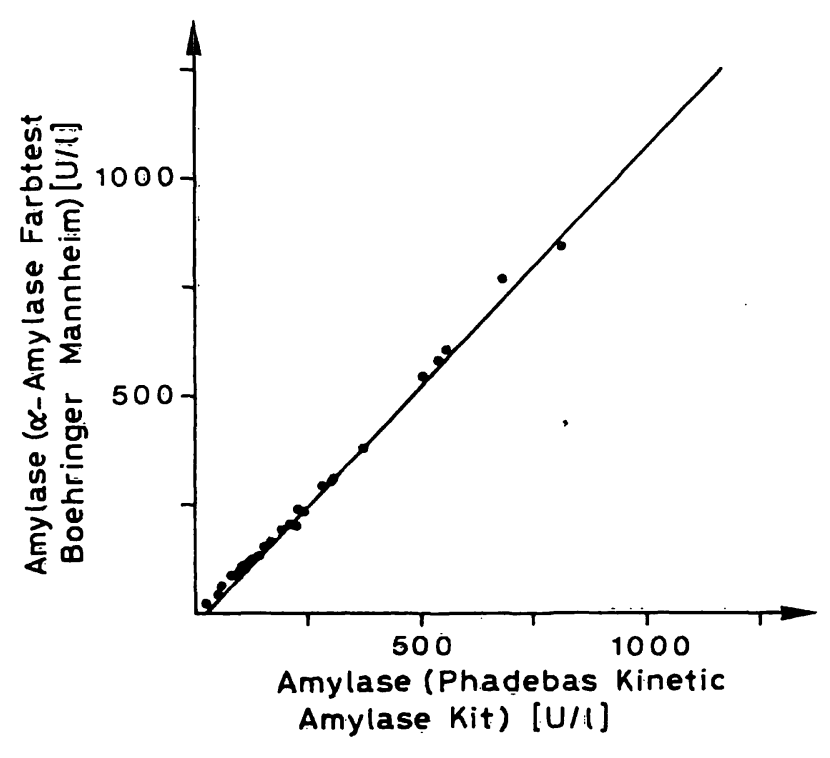

Fig. 1. The Boehringer continuous amylase method on a Hitachi 705 , compared to Phadebas ${ }^{\oplus}$ Kinetic Amylase Kit method in 28 patient serum samples.

$y=1.105 x-19.013, r=0.998, n=28$
Tab. 2. The within-day and day-to-day coefficients of variation in the total amylase assays with Hitachi $705 \mathrm{E}$.

A. Boehringer continuous method

\begin{tabular}{lll}
\hline $\begin{array}{l}\text { Total amylase } \\
\text { activity } \\
\text { concentration } \\
(U / 1)\end{array}$ & Coefficients of variation & \\
\hline 130 & $(\%)$ & $\begin{array}{l}\text { Day-to-day } \\
(\%)\end{array}$ \\
520 & $2.5(n=8)$ & $3.4(n=16)$ \\
2120 & $1.0(n=12)$ & $1.1(n=12)$ \\
& $1.1(n=12)$ & $1.2(n=13)$ \\
\hline
\end{tabular}

B. Phadebas ${ }^{\circledR}$ kinetic method

\begin{tabular}{lll}
$\begin{array}{l}\text { Total amylase } \\
\text { activity } \\
\text { concentration } \\
(U / 1)\end{array}$ & Coefficients of variation & \\
\hline 185 & Within-day & $\begin{array}{l}\text { Day-to-day } \\
(\%)\end{array}$ \\
370 & & $5.6(n=5)$ \\
445 & Variation & $\begin{array}{l}.2(n=10) \\
4.8(n=8)\end{array}$
\end{tabular}

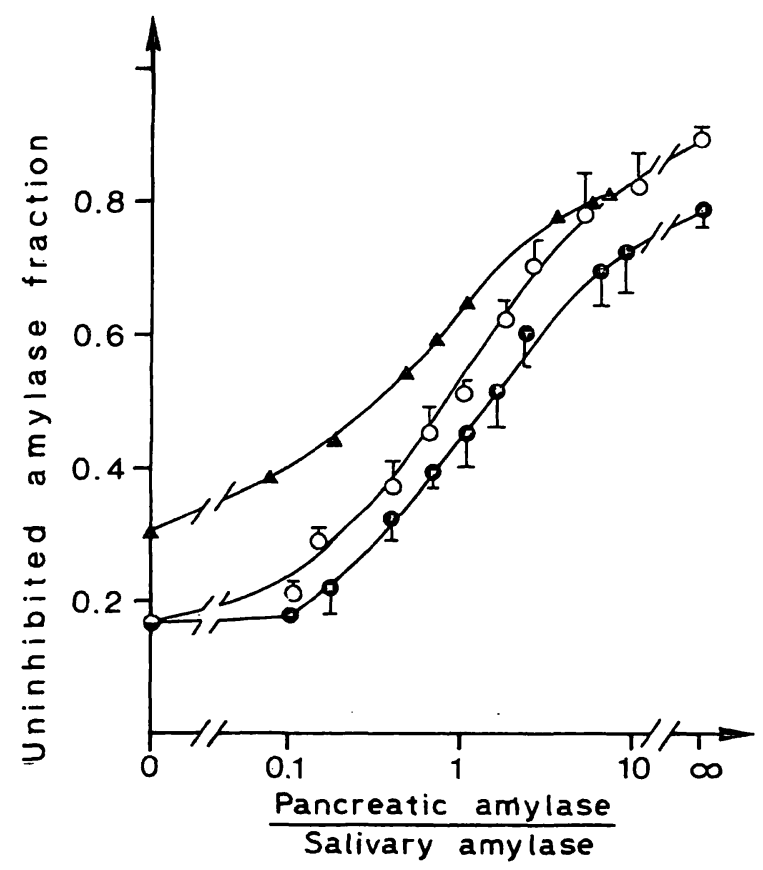

Fig. 2. Isoamylase standard curves relating the fraction of total amylase remaining uninhibited to the respective $\mathrm{P} / \mathrm{S}$ ratio. The curves were constructed by mixing pancreatic and salivary amylases in $\mathrm{P} / \mathrm{S}$ ratios in a range of $0.1-10$, and analysing the mixtures for amylase activity in the presence and absence of inhibitor. In the lower two curves each point is the mean of 7 analyses. The bars indicate \pm 2 SD.

(A) Phadebas ${ }^{\mathbb{*}}$ Kinetic IsoAmylase Kit (direct assay),

(O) Boehringer continuous amylase preincubated for 5 min with Phadebas ${ }^{\text {(O) }}$ inhibitor,

(๑) Boehringer continuous amylase preincubated for 5 min with Sigma inhibitor. 
The various commercially available inhibitors exhibited a marked variation in the inhibition with the Boehringer continuous method as illustrated in figure 2. This is probably due to different quality and purity of each commercial inhibitor. Recalibration of the assay is essential whenever the inhibitor batch is changed. The Phadebas ${ }^{\circledR}$ Kinetic Isoamylase Assay on Hitachi 705 yielded somewhat lower inhibition of the $S$ activity as compared to the Boehringer assay combined with preliminary inhibition. Apparently the $5 \mathrm{~min}$ incubation time with inhibitor in Hitachi 705 is not enough for a complete inhibition.

The inhibitor from Sigma was adopted for our routine amylase assay because of its commercial availability. In figure 3 the linearity of the assay is shown for the $P$ and $S$ amylase isoenzymes. The curves are constructed by analyzing total amylase and-isoamylase from a serial dilution of a patient serum with high total amylase activity concentration (3500 U/1) and low $\mathrm{P} / \mathrm{S}$ ratio. The assay for total amylase activity is linear at least to $3500 \mathrm{U} / 1$, but the total activity must be diluted below $1000 \mathrm{U} / 1$ for the isoamylase assay.

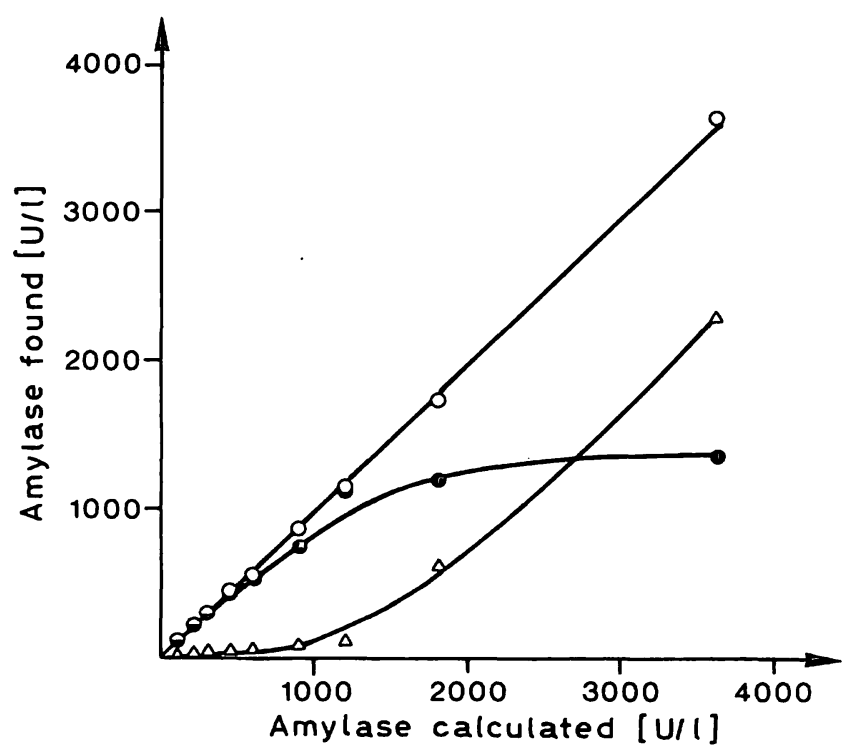

Fig. 3. Linearity of the amylase and isoamylase assay methods with Boehringer continuous amylase and Sigma inhibitor. A patient serum containing elevated total and $S$ amylase activity was diluted and assayed for total amylase and $P$ and $S$ isoamylases.

$(O)$ total activity, $(\Theta) S$ activity, $(\Delta) P$ activity concentration.

In table 3 the coefficients of variation are summarized for the within-day and day-to-day analyses of the $P$ and $S$ isoamylases. The coefficients were determined by assaying both patient serum samples containing normal or elevated total amylase, and high, normal and low P/S ratios and with Phadebas ${ }^{\circledR}$ human based standards. The Phadebas ${ }^{\circledR}$ standards gave somewhat higher variation coefficients.
Tab. 3. The within-day and day-to-day coefficients of variation in the isoamylase assays at various $\mathrm{P} / \mathrm{S}$ rations at normal or slightly elevated serum amylase concentration.

A. Boehringer continuous method

Human-based serum samples made in our laboratory.

\begin{tabular}{llllll}
\hline Ratio P/S & $\begin{array}{l}\text { Total } \\
\text { amylase } \\
\text { activity }\end{array}$ & $\begin{array}{l}\text { Coefficients of variation } \\
\text { Within-day } \\
(\mathbf{n = 8 )}\end{array}$ & $\begin{array}{l}\text { Day-to-day } \\
(\mathbf{n}=8)\end{array}$ \\
& $\begin{array}{l}\text { P type } \\
(\%)\end{array}$ & $\begin{array}{l}\text { S type } \\
(\%)\end{array}$ & $\begin{array}{l}\text { P type } \\
(\%)\end{array}$ & $\begin{array}{l}\text { S type } \\
(\%)\end{array}$ \\
\hline 6.5 & 390 & 7.9 & 9.8 & 5.7 & 20.5 \\
1.5 & 340 & 6.7 & 8.6 & 6.6 & 10.7 \\
0.2 & 280 & 5.1 & 3.4 & 12.0 & 2.1 \\
\hline
\end{tabular}

B. Boehringer continuous method

Pharmacia isoamylase standards $(n=20)$

\begin{tabular}{rrrrl}
\hline 8.0 & 204 & 10.6 & 18.5 & Variation \\
1.0 & 180 & 14.7 & 10.3 & not determined \\
0.1 & 380 & 15.5 & 6.7 & \\
\hline
\end{tabular}

C. Phadebas ${ }^{\circledR}$ Kinetic Isoamylase Assay

Pharmacia isoamylase controls $(n=8)$

\begin{tabular}{lllrr}
\hline & & & \\
8.0 & 450 & Variation & 9.2 & 13.8 \\
0.7 & 370 & not determined & 8.6 & 6.4 \\
\hline
\end{tabular}

\section{Isoamylase assays from serum samples}

Total serum amylase, and $\mathrm{P}$ and $\mathrm{S}$ isoamylase activities were determined from apparently healthy normal subjects ( 34 of both sexes, tab. 4), ages $32.2 \pm$ 10.3 years (mean $\pm S D$ ), range $16-58$ years. The total amylase activities were not statistically different in the sexes. Females however had significantly ( $p$ $<0.001$ ) higher $P$ isoamylase activity as compared to males.

Tab. 4. Amylase and isoamylase activity concentrations in normal subjects (means $\pm \mathrm{SD}$ ).

\begin{tabular}{lllrr}
\hline Subjects & n & \multicolumn{3}{l}{$\begin{array}{l}\text { Mean amylase activity concentration } \\
(\mathrm{U} / \mathrm{l}) \pm \mathrm{SD}\end{array}$} \\
& & Total & Pancreatic (P) & Salivary (S) \\
\hline Normal & & & & \\
$\delta$ & 34 & $157.8 \pm 43.1$ & $76.9 \pm 29.7$ & $81.1 \pm 41.3$ \\
$\wp$ & 34 & $179.6 \pm 5.9 .5$ & $11.4 \pm 43.4^{\mathrm{a}}$ & $70.3 \pm 37.9$ \\
\hline
\end{tabular}

Statistical significance of difference between males and females according to the Two Sample t-test: a $p<0.001$. 


\section{Discussion}

Automated total amylase assays have been introduced in routine laboratories, using the continuous mode of analysis with commercially available kits (6). One difficulty is, however, the variety of substrates used in the assay kits pending international recommendations.

In this work we have tested the continuous amylase assays from Boehringer Mannheim and Pharmacia Diagnostics on a Hitachi 705 analyzer. The methods correlated well with each other, but the Boehringer method seemed to be more readily suited for routine use in the Hitachi 705 analyzer by reason of its wider linearity. The methods also showed excellent precision when compared to each other.

The isoamylase assays in this work are based on inhibition with inhibitor from wheat (5). The methods were easily applied to the Hitachi 705 analyzer. The isoamylase assays with inhibitor are thus rapid and easy to perform as compared to other isoamylase methods, e.g. electrophoresis $(1-3)$ or radioimmunoassay (7). Based on appropriate absorbance changes, at least the Phadebas ${ }^{\circledR}$ Kinetic IsoAmylase test is also readily applicable to routine manual photometric measurement either at $37^{\circ} \mathrm{C}$ or at $30^{\circ} \mathrm{C}$.

The precision characteristics of our isoamylase assay are comparable to those given by $O^{\prime}$ Donnell et al. (5) for their inhibition methods or by Rammeloo et

\section{References}

1. Ojala, K. \& Harmoinen, A. (1975) Scand. J. Clin. Lab. Invest. $35,163-169$.

2. Skude, G. (1975) Scand. J. Clin. Lab. Invest. 35, 41-47.

3. Rammeloo, T., Haard, P. M. M. \& Beunis, M. H. (1982) Clin. Chem. 28, 145-149.

4. Takeuchi, T. (1979) Clin. Chem. 25, 1406-1410. al. (3) for their electrophoresis and inhibition methods. The isoamylase analyses from serum samples in normals showed a statistically very significant difference $(p<0.001)$ in $P$ isoamylase between females and males; the latter showed lower levels, which agrees with the findings of $O^{\prime}$ Donnell et al. (5).

The clinical value of serum isoamylase measurements is still a matter of controversy. The usefulness of the electrophoretic method has been criticized mainly because of the laborious methodology together with a somewhat questionable value in clinical decision-making. The present isoamylase test makes possible a fast and easy evaluation of pancreatic and salivary type isoamylase activities. Previous studies have shown that results of the inhibitor tests correlate with the electrophoretic method (3). Although a considerable bias between the methods may exist, further studies are however needed to assess whether this correlation is valid in all clinical situations. These studies are now in progress in our laboratory,and will be published later.

\section{Acknowledgements}

Phadebas ${ }^{\circledR}$ Kinetic Amylase and Kinetic IsoAmylase kits were generously provided by Star Oy, Tampere, Finland.
5. O'Donnell, M. D., FitzGerald, O. \& McGeeney, K. F. (1977) Clin. Chem. 23, 560-566.

6. Huang, W. Y. \& Tietz, N. W. (1982) Clin. Chem. 28, 15251527.

7. Boehm-Truitt, M., Harrison, E., Wolf, R. O. \& Notkins, A. L. (1978) Anal. Biochem. 85, 476-487. 
